\title{
Obsessive compulsive disorder in a patient with tuberous sclerosis and subependymal giant cell astrocytoma
}

\author{
Gabriela Roncada Haddad ${ }^{1}$, Flávio Ramalho Romero*1, Helio A. Miot ${ }^{2}$ \\ ${ }^{1}$ Hospital das Clínicas de Botucatu, Brazil \\ ${ }^{2}$ São Paulo State University, Botucatu, Brazil
}

\author{
Received: October 8, $2015 \quad$ Accepted: January 3, $2016 \quad$ Online Published: January 6, 2016 \\ DOI: $10.5430 /$ jst.v6n1p59 \\ URL: http://dx.doi.org/10.5430/jst.v6n1p59
}

\begin{abstract}
Tuberous sclerosis complex (TSC) is a multi-system disorder with autosomal dominant inheritance, which can affect the brain, heart, skin, kidneys, lungs, and retina. We present an obsessive-compulsive disorder patient, with classic dermatological findings and subependymal giant cell astrocytoma in TSC.
\end{abstract}

Key Words: Tuberous sclerosis complex, Subpendymal giant cell astrocytoma, Obsessive-compulsive disorder

\section{INTRODUCTION}

Tuberous Sclerosis complex (TSC) was first described in 1880 by Bourneville who observed the typical pathological features at postmortem examination in patients with mental retardation and seizure. ${ }^{[1]}$ Autosomal-dominant inheritance of mutations on TSC1 (Chr9q) or TSC2 (Chr16p) are associated with this disorder, classically presenting with sebaceous adenoma, seizures and mental retardation. ${ }^{[2]}$ Ectodermal and mesodermal cells are responsible for development of lesions in skin, nervous system, heart, kidney and other tissues. ${ }^{[3]}$

TSC may manifest with many neuropsychiatric disorders. The most common are psychosis, ${ }^{[4]}$ aggressive behavior and autism in children, ${ }^{[5]}$ and mood disorders in adults. ${ }^{[6]} \mathrm{Be}$ sides, many other neuropsychiatric problems have been reported, including psychotic syndromes, mania, eating disorders, and alcohol dependence. ${ }^{[7]}$ We report here a case of TSC patients with an uncommon array of manifestations.

\section{CASE}

A 16-year-old boy, with past history of seizures, was sent by psychiatry with a history of skin lesions and an obsession about cleanliness for the past 10 months. Psychiatric evaluation revealed intrusive and distressing ideas about his "fear of non-hygienic places" and human contact, and repetitive motor acts characterized by washing his hands every time he touch something. His seizures were characterized by sensitive symptoms on his left hand followed by loss of consciousness. Also, he has learning difficulty at school. Physical examination with skin diseases specialist showed multiple angiofibromas on the face (see Figure 1) and multiple hypomelanotic macuoles on the dorsum and legs. Neurological examination was normal. Electroencephalogram revealed an epileptogenic area in right temporal lobe. He was on oxcarbazepine $600 \mathrm{mg} / \mathrm{day}$ with good seizure control, and Fluoxetine $40 \mathrm{mg} /$ day without good control of obsessive-

*Correspondence: Flávio Ramalho Romero, MD, MSc, PhD; Email: frromero@ig.com.br; Address: Departamento de Neurologia e Psiquiatria, UNESP, Botucatu (SP), Brazil. 
compulsive disorder (OCD) symptoms. Computed Tomogram (CT) scan (see Figure 2) and Magnetic Resonance Images (MRI) of the brain showed a right lateral ventricular enlargement and a heterogeneous calcified $3 \mathrm{~cm} \times 3 \mathrm{~cm} \times 4$ $\mathrm{cm}$ lesion in the anterior horn of lateral ventricle. A transcortical approach was performed to remove the ventricular tumor, and anatomopathological exam reveled a subependymal giant cell astrocytoma (SEGA - WHO grade I). So, a TSC diagnosis with OCD was made. He was discharged in three days with normal neurological examination and good clinical condition.
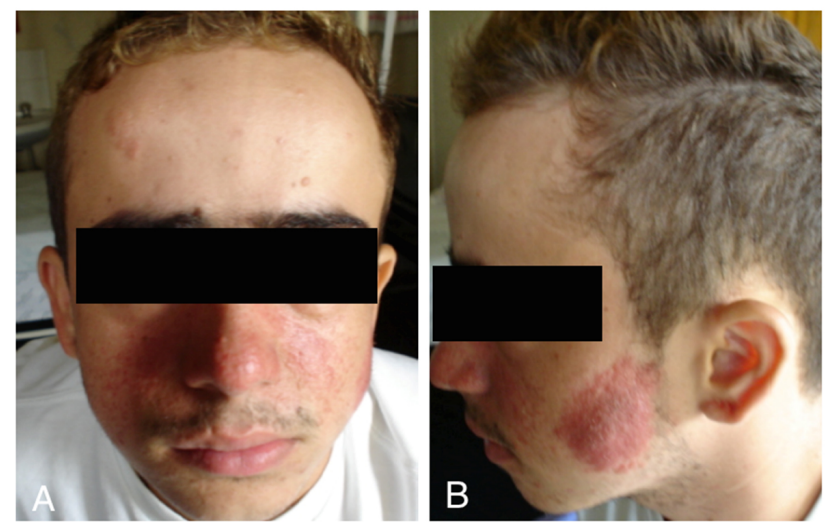

Figure 1. Multiple facial angiofibromas

Three months after surgery, he was neurologically intact and a new MRI showed good postoperative control, without residual tumor. He had improved his OCD symptoms with 20 $\mathrm{mg}$ /day Fluoxetine, and after six months, symptoms of OCD were totally under control.
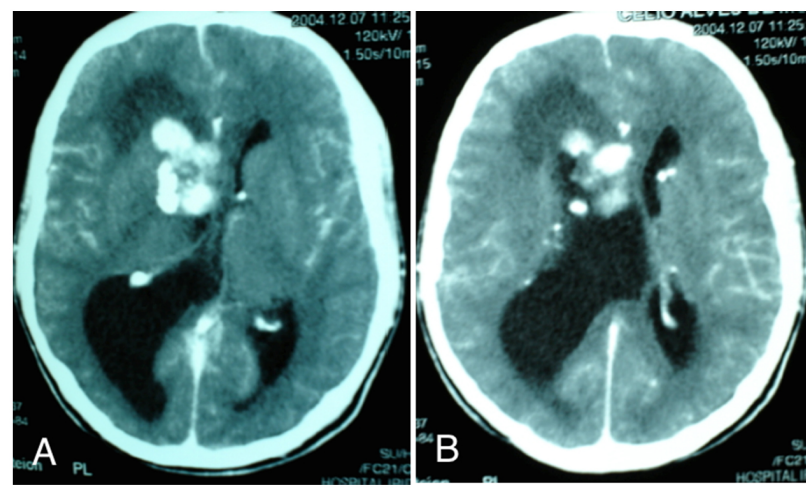

Figure 2. CT scan showing intraventricular tumor (A) with enlargement of right lateral ventricle (B)

\section{Discussion}

TSC is a phakomatosis characterized by seizure, mental retardation and skin findings, including congenital hypomelanotic macules and facial angiofibromas. Cutaneous lesions are often the initial clinical features, and TSC incidence is about 1/10000 birth. Besides TSC inheritance is autosomal dominant, the majority of newly recognized cases represent new spontaneous mutations. Some authors have suggested that about half demonstrated a linkage to chromosome $9 \mathrm{q} 34$ (TSC1), whereas the other half showed linkage to chromosome $16 \mathrm{p} 13$ (TSC2). ${ }^{[8]}$ But more recent larger epidemiological studies suggested the proportion is $20 \%$ TSC1 to $80 \%$ TSC2. ${ }^{[9]}$

Clinical findings may include cutaneous, ocular, neurologic, cardiovascular and renal manifestations. Most important cutaneous findings are hypomelanotic macules usually present at birth, café-au-lait macules, facial angiofibromas, shagreen patchs, periungual fibromas (Koenen tumors), molluscum pendulum, gingival fibromas and enamel pits. ${ }^{[4,8]}$ Our patient has multiple angiofibromas on the face and multiple hypomelanotic maculas on the dorsum and legs. In TSC the most important neurologic findings are infantile spasms, hypsarrhythmia, seizures, autism, attention deficit disorders, psychoses, multiple calcified subependymal nodules along the ventricular surface, subependymal giant cell astrocytomas, multiple cortical tubers. ${ }^{[10-13]}$ Our patient presented with seizures and a brain tumor compatible with subependymal giant cell astrocytoma. Also, TSC may be associated with retinal hamartomas, cardiac rhabdomyomas, arrhythmias, multiple bilateral renal angiomyolipomas, pulmonary lymphangioleiomyomatosis, and gastrointestinal hamartomatous polyps. ${ }^{[14,15]}$ None of these findings were observed in our case.

Almost all organs can be affected in TSC, but the most obvious features are cutaneous. So, dermatologic examination is critical in these patients. In addition, neuroimaging studies with CT and MRI are very important, also renal ultrasonography, electrocardiography (ECG), ophthalmologic examination, neuropsychiatric testing and CT examination of the lungs. Evaluation of other family members, especially the parents, is critical, and the genetic counseling is thus essential. ${ }^{[2,3,8,13-15]}$

Psychiatric manifestations are very common in cases of TSC. ${ }^{[7]}$ Although OCD has rarely been reported as an isolated problem in TSC it is common as part of Autistic spectrum disorder (ASD). So, cases of OCD, in the absence of ASD are rarely reported in the literature. ${ }^{[7,16,17]}$ TSC is a genetic disorder affecting every organ system, but disease manifestations vary significantly among affected individuals. The diverse and varied presentations and progression can be life threatening with significant impact on cost and quality of life. Management of the patient was carried out keeping in mind the control of grand mal seizures through optimiza- 
tion of treatment regime, assessment of patient's cognitive abilities and achievement of optimum level of adaptive functioning according to patient's cognitive abilities, behavioral modification aimed at reduction of undesirable behaviors and promotion of adaptive and socially desirable behaviors, detection and timely treatment of other manifestations of tuberous sclerosis to prevent complications. ${ }^{[18]}$ Our patient's treatment focused on brain tumor resection, seizure control, and obsessive-compulsive disorder management.

Some researchers have suggested a structural damage associated with OCD. Caudate nucleus and other basal ganglia structures, the cingulate and other limbic system components, and their connections with the frontal cortex have been hypothesized to comprise a disinhibited, reverberating neural circuit that gives rise to symptoms of OCD. ${ }^{[19]}$ So, in our case, tumor location could explain his psychiatric symptoms. Also, after tumor removal, he had improvement in his OCD symptoms with good clinical control.

TSC is a complex disease affecting multiple organs and systems, and psychiatric manifestations are commonly reported. Obsessive-compulsive disorder, separate from ASD is not a commonly reported finding, clinicians should be aware about the development of these symptoms in TSC patients. To date, this is the first report of TSC with OCD in an adolescent, and other two cases were described in adult patients ${ }^{[17,20]}$ and the first report of OCD improving post surgery for SEGA.

\section{CONFLicts OF INTEREST Disclosure}

The author declares that there is no conflict of interest statement.

\section{REFERENCES}

[1] Bourneville DM. Sclerose Tubereuse des circumvolution cerebrales: Idiote et epilepsie hemiplegique. Arch Neurol. 1880; 1: 81-91.

[2] Nevin NC, Pearce WG. Diagnostic and genetic aspects of tuberous sclerosis. J Med Genet. 1968; 5: 273-80. http://dx.doi.org/10. $1136 / j m g$. 5.4.273

[3] Osbourne JP. Diagnosis of tuberous sclerosis. Arch Dis Child. 1988; 63: 1423-5. http://dx.doi.org/10.1136/adc.63.12.1423

[4] Sedky K, Hughes T, Yusufzie K, et al. Tuberous sclerosis with psychosis. Psychosom. 2003; 44: 521-2. PMid:14597689. http: //dx.doi.org/10.1176/appi.psy.44.6.521-a

[5] Hunt A, Dennis J. Psychiatric disorder in children with tuberous sclerosis. Dev Med Child Neurol. 1987; 29: 190-8. PMid:3582788. http: //dx.doi.org/10.1111/j.1469-8749.1987.tb02135.x

[6] Khanna R, Borde M. Mania in a five year old child with tuberous sclerosis. Br J Psychiatry. 1989; 155: 117-9. http://dx.doi.org /10.1192/bjp.155.1.117

[7] Muzykewicz DA, Newberry P, Danforth N, et al. Psychiatric comorbid conditions in a clinic population of 241 patients with tuberous sclerosis complex. Epilepsy Behav. 2007; 11: 506-13. PMid:17936687. http://dx.doi.org/10.1016/j.yebeh. 200 7.07 .010

[8] Schwartz RA, Fernández G, Kotulska K, et al. Tuberous sclerosis complex: advances in diagnosis, genetics, and management. J Am Acad Dermatol. 2007; 57(2): 189-202. PMid:17637444. http: //dx.doi.org/10.1016/j.jaad.2007.05.004

[9] Narayanan V. Tuberous sclerosis complex: genetics to pathogenesis. Pediatr Neurol. 2003; 29(5): 404-9. PMid:14684235. http: //dx.doi.org/10.1016/j.pediatrneurol.2003.09.002

[10] Adriaensen ME, Schaefer-Prokop CM, Stijnen T, et al. Prevalence of subependymal giant cell tumors in patients with tuberous sclerosis and a review of the literature. Eur J Neurol. 2009; 16(6): 691-6. PMid:19236458. http://dx.doi.org/10.1111/j.1468-1331. $2009.02567 . x$
[11] Nabbout R, Santos M, Rolland Y, et al. Early diagnosis of subependymal giant cell astrocytoma in children with tuberous sclerosis. $\mathrm{J}$ Neurol Neurosurg Psychiatry. 1999; 6(3): 370-5. http://dx.doi .org/10.1136/jnnp.66.3.370

[12] Goh S, Butler W, Thiele EA. Subependymal giant cell tumors in tuberous sclerosis complex Neurology. 2004; 63(8): $1457-$ 61. PMid:15505165. http://dx.doi.org/10.1212/01. WNL. 00 $00142039.14522 .1 \mathrm{~A}$

[13] DiMario FJ Jr. Brain abnormalities in tuberous sclerosis complex. J Child Neurol. 2004; 19(9): 650-7. PMid:15563010.

[14] Crino PB, Nathanson KL, Henske EP. The tuberous sclerosis complex. N Engl J Med. 2006; 355: 1345-56. PMid:17005952. http: //dx.doi.org/10.1056/NEJMra055323

[15] de Vries PJ, Prather PA. The tuberous sclerosis complex. N Engl J Med. 2007; 356(92): 93-4.

[16] Bhattacharya A, Das S, Nath K, et al. Atypical presentation of tuberous sclerosis and obsessive compulsive disorder in an adult male. Ann Indian Acad Neurol. 2012; 15(2): 161-2. PMid:22566737. http://dx.doi.org/10.4103/0972-2327.95007

[17] Hassan IK, Looi JC, Velakoulis D, et al. Psychosis with obsessivecompulsive symptoms in tuberous sclerosis. J Clin Neurosci. 2014; 21(5): 867-9. PMid:24211143. http://dx.doi.org/10.1016/j .jocn. 2013.08.005

[18] Krueger DA, Northrup H. Tuberous sclerosis complex surveillance and management: recommendations of the 2012 International Tuberous Sclerosis Complex Consensus Conference. Pediatr Neurol. 2013 Oct; 49(4): 255-65. PMid:24053983. http://dx.doi .org/10.10 $16 / \mathrm{j} \cdot$ pediatrneurol.2013.08.002

[19] Insel TR. Toward a neuroanatomy of obsessive-compulsive disorder. Arch Gen Psychiatry. 1992; 49: 739-44. http://dx.doi.org/10. 1001/archpsyc. 1992.01820090067011

[20] Hassan IK, Looi JC, Velakoulis D, et al. Psychosis with obsessivecompulsive symptoms in tuberous sclerosis. J Clin Neurosci. 2014; 21(5): 867-9. PMid:24211143. http://dx.doi.org/10.1016/j .jocn. 2013.08.005 